\title{
KORELASI ANTARA KECENDERUNGAN TEOLOGI DENGAN OPINI ETOS KERJA \\ Zainul Muhibbin
}

\begin{abstract}
The problem underlying this research is a perception of slow development and advancement labeled to Indonesian as a result of low working spirit in comparison to its neighboring countries known as "Little Dragons" such as South Korea, Taiwan, China and Singapore. Moslem dominate Indonesia as a major religion; whether Aqidah has influences on a person's working spirit is the main focus of this research. It is very important to prove whether there is a positive relationship between a person's Aqidah and his/her working spirit.

Data analysis is carried data tabulation method and correlation analysis (Pearson Correlation). The result show that almost, the correlation of the variables shows quite low correlation between the tendency of Aqidah thought and working spirit. It can be concluded that Aqidah is not the sole factor influencing the person working spirit. There must other factors outside Aqidah in particular and religion in general.
\end{abstract}

Kata kunci: Aqidah, working spirit, not the sole factor.

Artikel ini sebenarnya adalah bentuk lain dari laporan hasil penelitian yang telah dilakukan penulis tentang "Korelasi antara Kecenderungan Pemikiran Aqidah Mahasiswa ITS Dengan Opininya tentang Etos Kerja”. Penelitian ini dilakukan untuk membuktikan sekaligus menjawab permasalahan tentang ada dan tidaknya korelasi antara aqidah agama dengan etos kerja. Hal ini perlu diteliti karena etos kerja sangat terkait dengan masalah produktivitas yang menjadi unsur penting kemajuan suatu bangsa. Maka pada gilirannya agama nampaknya memiliki peranan penting dalam hal ini.

Agama Islam adalah agama yang turun dari Allah sebagai rahmat bagi semesta alam. Ajaran Islam yang secara garis besar meliputi aspek aqidah, syari'ah dan akhlak telah mencakup seluruh sisi kehidupan manusia, yaitu dari kehidupan spiritual sampai kehidupan empirik (fisik). Secara psikologis, dua sisi kehidupan manusia ini (spiritual dan fisik) saling mempengaruhi. Termasuk dalam masalah etos kerja yang melatarbelakangi kinerja seseorang, sering kali 
terkait dengan sisi spiritualisme orang tersebut. Dengan kata lain, kecenderungan pemikiran seseorang dalam masalah aqidah (keyakinan) dapat berpengaruh pada sikap dan karakteristik orang tersebut dalam bekerja. Masalah ini akan berlanjut pada masalah produktivitas manusia baik secara individual maupun kolektif.

Menurut Max Weber dalam The Protestant Ethic and The Spirit of Capitalism, sebagaimana dikutip Taufik Abdullah, bahwa orang-orang Protestan lebih sukses dalam kehidupan ekonominya, karena dari fakta sosiologis yang ditemukannya di Jerman, bahwa sebagian besar dari pemimpin-pemimpin perusahaan, pemilik modal serta personil teknis dan komersial tingkat atas adalah orang-orang Protestan, bukannya Katolik. Dalam Calvinisme (sekte dalam Protestan) Tuhan mengharuskan umatnya tidak saja kerja yang baik, tetapi suatu hidup dari kerja yang baik itu digabungkan dalam suatu sistem yang terpadu, ini adalah Beruf (Abdullah, 1982). Selanjutnya Weber menambahkan argumentasinya, bahwa sekte-sekte Protestan sengaja menghubungkan pemberkatan kekayaan dengan tingkahlaku (kerja), dan ini merupakan ibadat. Prinsip-prinsip mereka memang sangat rasional dan realistis (Weber, 1982). Senada dengan hal tersebut, Hadari Nawawi dalam Manajemen Sumber Daya Manusia untuk Bisnis yang Kompetitif berpendapat, bahwa suasana psikologis seseorang sangat besar pengaruhnya pada pelaksanaan pekerjaannya (Nawawi, 2001). Ini berarti ada indikasi keterkaitan antara etos kerja seseorang dengan masalah spiritualisme.

Nurcholish Madjid dalam melihat masalah etos kerja perspektif ajaran Islam tidak mengaitkan dengan latar belakang masalah teologi (aqidah), akan tetapi lebih mengaitkan dengan masalah niyat (komitmen) yang mendasari suatu kerja/pekerjaan, dan konsep ihsan dalam kerja, yaitu mengerjakan sesuatu demi mendapatkan ridha Allah, serta prinsip bahwa kerja merupakan bentuk perwujudan diri manusia (Madjid, 1992). Dengan demikian Nurcholish Madjid lebih melihat pada aspek etika Islam. Sementara itu, Harun Nasution memandang

Jsh Jurnal Sosial Humaniora, Vol.1 No.2, November 2008 
ada keterkaitan antara pemikiran teologi Islam dengan etos kerja yang berlanjut pada masalah produktivitas. Dia berpendapat, bahwa kalau nasib manusia telah ditentukan Tuhan sejak semula, dalam arti perbuatan manusia merupakan ciptaan Tuhan (Jabbariyah), maka produktivitas masyarakat yang menganut paham (fatalisme) ini akan rendah sekali. Tetapi dalam masyarakat yang menganut paham bahwa manusialah yang menentukan nasibnya dan manusia pula yang menciptakan perbuatannya (Qadariyah), produktivitas akan tinggi (Nasution, 1995).

Terlepas dari perbedaan pandangan antara Nurcholish Madjid dengan Harun Nasution, di kalangan masyarakat kita selalu ada sikap pasrah yang mereka miliki. Hal ini menjadi bukti bahwa ada indikasi keterkaitan antara etos kerja masyarakat Indonesia dengan keyakinan terhadap takdir. Sehingga jika kecenderungan pemikiran aqidah masyarakat itu kepada paham yang fatalistis maka sedikit banyak akan membawa dampak negatif terhadap masalah produktivitas, dan jika kecenderungan pemikiran aqidah masyarakat itu kepada paham kebebasan berkehendak dan berbuat maka dampaknya akan lebih positif (Muhibbin, 2004).

Pada dekade tahun sembilan puluhan bangsa Indonesia disinyalir sebagai bangsa yang menderita kelemahan dalam masalah etos kerja, ditambah lagi dengan tingkat korupsinya yang cukup tinggi. Maka diprediksi Indonesia sulit maju dalam tempo cepat dikarenakan etos kerja dan etika yang cacat itu. Kita ingat negara-negara seperti Korea Selatan, Taiwan, Cina dan Singapura yang dijuluki sebagai "Little Dragons" telah mengalami kemajuan yang sangat pesat dan lebih cepat dari pada Indonesia. Julukan Dragons bagi negara-negara tersebut bisa dimaklumi karena bangsa negara-negara itu mayoritas masyarakatnya adalah konfusianis, yaitu penganut ajaran Kong Hucu dengan ular naga sebagai binatang mitologis dalam sistem kepercayaan mereka. Dengan kalimat lain dapat dikatakan, bahwa negara-negara "Little Dragons" itu menjadi maju berkat ajaran atau etika Kong Hucu. Ini menunjukkan bahwa etos kerja bangsa-bangsa itu 
menjadi baik karena pengaruh dari etika dan sistem kepercayaan dalam Kong Hucu (Madjid, 1992).

Indonesia adalah negara yang mayoritas penduduknya beragama Islam, maka predikat apapun yang diberikan orang tidak akan lepas begitu saja dari latar belakang agama (aqidah) yang dianut oleh mayoritas penduduk Indonesia itu. Jika dikatakan bahwa etos kerja bangsa Indonesia buruk dan rendah, apalagi ditambah dengan tingkat korupsinya yang tinggi, maka jelas ini akan mengakibatkan kontra produktif bagi bangsa Indonesia. Maka yang menjadi permasalahan adalah; Adakah keterkaitan antar etos kerja masyarakat Indonesia dengan aqidah yang mereka anut? Sementara itu kita ketahui bahwa dalam aqidah Islam terdapat beberapa aliran pemikiran (teologi) yang masing-masing memiliki perbedaan pandangan dalam beberapa hal. Maka lebih spesifik permasalahannya adalah; Apakah kecenderungan pemikiran teologi seseorang terhadap aliran-aliran yang ada memiliki korelasi dengan etos kerja?

Permasalahan ini cukup menarik dan penting diteliti untuk membuktikan ada dan tidaknya korelasi antara kecenderungan pemikiran teologi dengan etos kerja seseorang, setidaknya bagi mahasiswa ITS sebagai generasi muda bangsa Indonesia dan calon sarjana atau ilmuwan yang akan berkiprah untuk bangsa, yang diharapkan dapat membawa Indonesia menjadi negara besar dan maju. Berdasarkan latar belakang ini maka penelitian tentang Korelasi antara Kecenderungan Pemikiran Aqidah Mahasiswa ITS dengan Opininya tentang Etos Kerja dilakukan. Tujuan penelitian ini adalah untuk mengetahui arah kecenderungan pemikiran teologi mahasiswa dan opininya dalam konteks etos kerja, serta menjawab permasalahan ada dan tidaknya korelasi antara kecenderungan pemikiran teologi dengan opini etos kerja.

Penelitian ini difokuskan pada permasalahan kecenderungan teologi di satu sisi dan opini etos kerja di sisi lain, selanjutnya diteliti untuk melihat korelasi antara keduanya. Mahasiswa, sebagai populasi dalam penelitian ini, merupakan bagian dari masyarakat intelektual. Oleh karena itu ruang lingkup penelitian 
(kajian) adalah aspek intelektualitas, yaitu kecenderungan teologi dan opini etos kerja. Hal ini karena mahasiswa yang menjadi populasi penelitian, diasumsikan masih belum bekerja, sehingga permasalahan etos kerja yang dilihat dari mahasiswa adalah opininya.

Mengenai metodologi dalam penelitian ini, pengumpulan data dilakukan dengan observasi lapangan. Teknik analisa data menggunakan tabulasi data, yang meliputi tabel distribusi frekuensi dan tabulasi silang (crosstabulation) untuk analisis data deskriptif (Anwar, 1999). Dan untuk analisis korelasi antara variabel menggunakan program SPSS (Statistical Package for Social Seciences) (Sugiyono, 1999). Selanjutnya, pembahasan dalam artikel ini menggunakan sistematika yang meliputi bagian pendahuluan, Hasil Penelitian yang mencakup permasalahan kecenderungan teologi dan opini etos kerja, Pembahasan yang meliputi analisis korelasi dan temuan, kemudian diakhiri dengan Penutup yang terdiri dari kesimpulan dan saran.

\section{Kecenderungan Teologi}

Aqidah merupakan satah satu aspek dalam ajaran Islam. Dan di dalam aqidah Islam (teologi) ini terdapat ajaran tentang taqdir (Qadla' dan Qadar). Pengertian taqdir secara etimologis adalah, bahwa kata taqdir berasal dari akar kata (bahasa Arab) "Qadara” yang antara lain berarti mengukur, memberi kadar atau ukuran. Maka jika dikatakan: "Allah telah mentakdirkan demikian”, itu artinya "Allah telah memberi kadar/ukuran/batas tertentu dalam diri, sifat atau kemampuan maksimal makhluk-Nya" (Shihab, 1996). Secara terminologis, dipahami bahwa Allah mentakdirkan segala sesuatu dalam dua cara, yaitu (1). Memberikan Qudrah (kekuatan) kepada segala sesuatu, dan (2). Membuat segala sesuatu dengan ukuran tertentu dan cara-cara tertentu menurut kebijaksanaan. Atau dapat dikatakan bahwa takdir adalah sebuah ketetapan atau ukuran yang melekat pada sekalian makhluk Allah (Ali, 1977).

Berkaitan dengan masalah takdir, dalam teologi Islam terdapat beberapa perbedaan pendapat di kalangan ulama teologi yang kemudian menjadi kelompokkelompok (aliran) teologi. Setidaknya ada tiga aliran dalam masalah ini, yaitu: 
Pertama, Jabbariyah. Tokoh utamanya adalah Jahm bin Shafwan al-

Khurrasani. Aliran ini berpendapat bahwa manusia bukanlah pencipta perbuatannya sendiri, dan perbuatan-perbuatannya itu sama sekali tidak dapat diidentikkan (nisbah) kepadanya. Inti pendapat ini adalah menafikan istitha'ah (kemampuan, kesanggupan dan daya) bagi manusia, dan semua perbuatan manusia adalah hanya majburah (keterpaksaan) belaka yang merupakan ciptaan Allah semata (Zahrah, 1996). Kedua, Qadariyah. Aliran ini dapat dikatakan lahir sebagai reaksi dari aliran Jabbariyah. Aliran ini berpendapat bahwa semua perbuatan manusia adalah karena kehendaknya sendiri dan bebas dari campur tangan kehendak Allah, (paham ini kemudian dianut oleh golongan Mu'tazilah). Ma'bad bin Khalid al-Juhani (tokoh penting aliran ini) mengatakan: "Semua urusan ditetapkan sekarang. Artinya tidak ada qadr (Allah), karena semua ketentuan ditentukan sekarang (oleh manusia)" (Ibid., 1996). Ketiga, Ahlus Sunnah wal Jama'ah (Sunni). Aliran ini muncul seakan-akan sebagai jalan tengah dari dua aliran sebelumnya. Aliran ini sering diidentikkan dengan tiga tokohnya yang menonjol, yaitu Abu al-Hasan al-Asy'ari, Abu Manshur al-Maturidi dan Ibnu Taimiyah (al-Syahrastani, t.t).

Al-Asy'ari berpendapat bahwa sesuatu yang dikehendaki Allah akan terjadi, dan sesuatu yang tidak dikehendaki-Nya tidak akan terjadi. Artinya, seseorang tidak akan sanggup melakukan sesuatu sebelum Allah melakukannya (menghendakinya), dan seseorang tidak bisa melepaskan diri dari Allah dan tidak mampu keluar dari pengetahuan-Nya, tidak ada pencipta melainkan Allah. Maka manusia tidak sanggup menciptakan sesuatu (perbuatan), tetapi ia sanggup melakukan kasab (usaha). Al-Maturidi berpendapat bahwa manusia tidak mempunyai kemampuan dalam perbuatannya karena hal itu merupakan takdir Allah, hanya saja kebijaksanaan Allah menghendaki adanya ikhtiyar (daya upaya) sebagai potensi yang dimiliki manusia. Dan Ibnu Taimiyah berpendapat, bahwa perbuatan hamba (manusia) disandarkan kepadanya, dan yang menciptakan perbuatan itu adalah Allah, karena Allah lah yang menciptakan kekuatan yang bersifat aktif terhadap suatu perbuatan, sedangkan pelaksanaannya adalah hamba. 
Dan nisbah (penyandaran) itu adalah dalam bentuk al-tanawul (pencapaian) (Zahrah, 1996). Singkatnya, menurut aliran Sunni, perbuatan manusia tidak bisa terlepas dari takdir Allah tapi manusia diberi potensi untuk berikhtiar.

Bertitik tolak dari penjelasan di atas maka kecenderungan pemikiran terhadap aliran-aliran yang ada mengacu pada paham (pendapat) aliran-aliran tersebut, yaitu: Jabbariyah, memiliki paham bahwa semua perbuatan manusia merupakan ciptaan Allah semata, dan manusia bukanlah pencipta perbuatannya sendiri. Maka manusia hanya menerima apapun takdir Allah (al-Syahrastani, t.t.). Qadariyah, memiliki paham bahwa semua perbuatan manusia ditentukan sendiri, bukan karena takdir Allah. Maka nasib manusia ditentukan oleh manusia sendiri. Sunni, memiliki paham bahwa semua perbuatan manusia ada kaitannya dengan takdir Allah, tapi Allah memberi manusia potensi untuk melakukan usaha (kasab) dan upaya (ikhtiyar). Maka manusia dapat merubah nasibnya karena izin Allah (Zahrah, 1996).

Selanjutnya, kecenderungan teologi mahasiswa terhadap aliran-aliran pemikiran yang dimaksud digali dari tiga elemen variabel, yaitu:

a. Pendapat responden mengenai paham dalam aliran-aliran teologi yang ada. Variabel ini memberikan indikasi tentang arah kecenderungan responden terhadap salah satu aliran dari aliran-aliran yang ada. Sehingga dapat diketahui, apakah responden cenderung kepada aliran Jabbariyah, Qadariyah atau Sunni.

b. Sikap responden terhadap prinsip-prinsip yang dipegangi oleh aliran-aliran tersebut. Variabel ini memberikan indikasi tentang tingkat kecenderungan responden terhadap salah satu aliran. Dari sikapnya itu dapat diketahui seberapa kuat kecenderungan responden terhadap aliran pemikiran yang dipilih/dipegangi.

c. Persepsi responden yang dikaitkan dengan paham dan prinsip dari aliran-aliran tersebut. Variabel ini memberikan indikasi tentang konsistensi kecenderungan responden terhadap salah satu aliran. Dari persepsi itu dapat dilihat sejauh 
mana konsistensi responden dalam memegangi paham dan prinsip dari aliran pemikiran yang dia pegangi.

Berdasarkan tiga elemen variabel tersebut sebagai indikator kecenderungan teologi, data yang dihasilkan dari penelitian yang dilakukan menunjukkan bahwa responden yang cenderung beraliran Jabbariyah adalah $0,51 \%$, yang cenderung beraliran Qadariyah adalah 1,03\% dan yang cenderung beraliran Sunni adalah 98,46\%. Dari sini jelaslah bahwa mayoritas responden adalah beraliran Sunni. Atau dapat dikatakan bahwa mayoritas mahasiswa (populasi) kecenderungan teologinya adalah Sunni.

\section{Opini Etos Kerja}

Istilah "Etos Kerja" merupakan gabungan dari dua kata; etos dan kerja. Kata etos berasal dari bahasa Yunani, yaitu ethos yang berarti watak atau karakter. Maka pengertiannya, etos adalah karakteristik (watak), sikap, kebiasaanserta kepercayaan yang bersifat khusus tentang seseorang (individu) atau sekelompok manusia (Madjid, 1992). Dalam Kamus Besar Bahasa Indonesia dikatakan bahwa etos kerja adalah semangat kerja yang menjadi ciri khas dan keyakinan seseorang atau sesuatu kelompok (Departemen Pendidikan Nasional, 1991).

Pembahasan ini menyangkut permasalahan opini mahasiswa yang berkaitan dengan etos kerja. Permasalahan ini diangkat dan dibahas untuk menjawab permasalahan tentang; bagaimana opini dan sikap mahasiswa dalam kaitannya dengan masalah kerja (profesi dan karier)? Untuk menjaring opini tersebut maka dilakukan upaya mengetahui sikap responden terhadap lima variabel yang dapat menjadi unsur-unsur etos kerja, yaitu:
a. Motivasi (alasan) kerja
b. Pola (cara) kerja
c. Tujuan kerja
d. Semangat kerja
e. Tekad kerja

Jsh Jurnal Sosial Humaniora, Vol.1 No.2, November 2008 
Berangkat dari pengertian dan parameter masing-masing variabel tersebut, responden diminta pendapatnya untuk bisa dilihat opininya mengenai hal-hal yang berkaitan dengan masalah kerja.

Berdasarkan hasil penelitian yang dilakukan, berdasarkan lima variabel etos kerja tersebut, diperoleh data bahwa prosentase pada kategori dari masingmasing variabel tersebut menunjukkan angka yang sedikit berbeda, meskipun kebanyakan sama. Lebih jelas dapat dikatakan bahwa; pada variabel motivasi kerja, prosentase terbesar dari responden adalah kategori etos kerja "tinggi". Pada variabel pola kerja, prosentase terbesar adalah kategori "tinggi". Pada variabel tujuan kerja, prosentase terbesar adalah kategori "sedang". Pada variabel semangat kerja, prosentase terbesar adalah "sedang". Dan pada variabel tekad kerja, prosentase terbesar adalah "tinggi".

Kemudian untuk dapat membuat kesimpulan tentang etos kerja berdasarkan opini yang ada, maka dibuat rekapitulasi terhadap data dari variabelvariabel etos kerja tersebut. Kesimpulan yang dihasilkan dari rekapitulasi yang dilakukan terhadap setiap kategori yang ada (rendah, sedang dan tinggi), yang meliputi seluruh variabel etos kerja (motivasi, pola, tujuan, semangat dan tekad kerja) adalah, secara keseluruhan dapat dikatakan bahwa opini responden dalam konteks etos kerja adalah, kategori "rendah" ada 4,4\%, kategori "sedang" ada 35,4\% dan kategori "tinggi" ada 59\%. Dengan demikian prosentase terbesar etos kerja responden adalah "tinggi", disusul di bawahnya adalah "sedang" dan baru kemudian yang "rendah", dengan prosentase yang jauh lebih kecil. Atau dapat dikatakan, bahwa mayoritas mahasiswa (populasi) etos kerjanya adalah tinggi.

\section{Korelasi Kecenderungan Teologi dan Etos Kerja}

Data hasil penelitian di atas menunjukkan, bahwa pada aspek kecenderungan teologi mayoritas mahasiswa adalah beraliran Sunni, sementara itu pada aspek opini etos kerja mayoritas mahasiswa adalah beretos kerja tinggi. Kalau kita kembali kepada pendapat Harun Naution maka asumsinya adalah, bagi yang berpaham Jabbariyah, etos kerjanya akan buruk dan produktivitasnya juga akan rendah, karena mereka selalu dan hanya mengandalkan takdir Allah. Bagi 
yang berpaham Qadariyah, etos kerjanya akan lebih baik dan produktivitasnya akan tinggi, karena mereka memiliki semangat kerja yang sangat tinggi. Dan bagi yang berpaham Sunni, maka etos kerjanya akan cukup baik dan produktivitasnya pun tidak rendah (sedang), karena mereka menganggap bahwa manusia memiliki potensi untuk berikhtiyar (upaya/usaha) di samping ada kehendak Allah. Taufik Abdullah mengatakan: "Pertanyaan yang juga bisa menjadi dasar argumen adalah sejauh manakah kemungkinan agama sebagai jalan untuk mendukung pembangunan, dalam arti sebagai unsur motivasi dalam sistem tindakan?" (Abdullah, 1982).

Untuk membuktikan adanya korelasi antara kecenderungan teologi dengan opini etos kerja maka analisanya dilakukan dengan metode tabulasi silang (crosstabulation) dan analisis korelasi antara kedua aspek tersebut. Dan metodologi kajiannya adalah dengan mengkorelasikan antara kecenderungan responden terhadap aliran-aliran teologi (Jabbariyah, Qadariyah dan Sunni) dengan variabel-variabel yang menjadi unsur etos kerja (motivasi, pola, tujuan, semangat dan tekad kerja).

Dari hasil analisis korelasi yang telah dilakukan, diketahui bahwa ternyata antara aliran dengan motivasi kerja, tingkat korelasinya bisa dikatakan sangat lemah $(0,154)$ karena tingkat korelasi kuat adalah 0,5 dan nilai signifikansinya juga di bawah level normal (signifikan) yaitu 0,031 padahal level signifikan adalah 0,05 . Oleh karena itu dapat dikatakan bahwa antara aliran dengan motivasi kerja tidak terdapat korelasi, karena tingkat korelasi yang sangat lemah, ditambah tingkat signifikansinya di bawah level signifikan. Demikian juga antara aliran dengan pola kerja dapat dikatakan tidak ada korelasi, karena angkanya adalah 0,062. Sedangkan nilai signifikansinya adalah 0,387 jelas berada jauh di atas level signifikan. Dengan kata lain, antara aliran dengan pola kerja tidak didapati adanya korelasi, karena angka yang menunjukkan tingkat korelasi justru minus dan keadaan ini ternyata sangat signifikan.

Jsh Jurnal Sosial Humaniora, Vol.1 No.2, November 2008 
Selanjutnya, mengenai korelasi antara aliran dengan tujuan kerja, diketahui terdapat korelasi antara keduanya meskipun cukup lemah, yaitu 0,140, dan angka signifikansinya adalah 0,055 , berarti data korelasi tersebut cukup signifikan. Dengan demikian dapat dikatakan bahwa ternyata antara aliran dengan tujuan kerja terdapat korelasi, meskipun korelasinya cukup lemah. Mengenai analisis tentang korelasi antara aliran dengan semangat kerja, hasilnya sangat lemah, yaitu 0,035, dan data ini ternyata sangat signifikan, karena angka signifikansinya mencapai 0,632 . Ini dapat dikatakan bahwa terdapat korelasi antara aliran dengan semangat kerja, meskipun sangat lemah. Dan mengenai analisis korelasi antara aliran dengan tekad kerja, ternyata tingkat korelasinya juga sangat lemah, karena angkanya adalah 0,058, sedangkan nilai signifikansinya adalah 0,418 , ini jelas sangat signifikan. Maka dapat dikatakan bahwa antara aliran dengan tekad kerja telah didapati adanya korelasi, namun tingkat korelasinya sangat lemah.

Berdasarkan pembahasan di atas, secara keseluruhan dapat dikatakan bahwa dari lima variabel etos kerja ternyata dua di antaranya tidak memiliki korelasi dengan kecenderungan teologi, yaitu variabel motivasi kerja dan pola kerja. Dan tiga variabel selebihnya didapati memiliki korelasi dengan kecenderungan teologi, meskipun tingkat korelasinya lemah, bahkan ada yang sangat lemah. Tingkat korelasi yang lemah khususnya terjadi pada variabel tujuan kerja, dan dua variabel sisanya (semangat dan tekad kerja) korelasinya sangat lemah. Berdasarkan kenyataan tersebut maka dapat disimpulkan bahwa korelasi antara kecenderungan teologi mahasiswa dengan opini etos kerja adalah sangat lemah.

Jika keadaan riilnya memang seperti yang terungkap di atas maka berarti aspek kecenderungan teologi bukanlah satu-satunya faktor yang dapat mempengaruhi etos kerja seseorang, melainkan masih terbuka lebar kemungkinan adanya faktor-faktor lain yang dapat mempengaruhi etos kerja seseorang. Faktorfaktor lain yang dimaksud bisa jadi merupakan faktor-faktor di luar masalah teologi (aqidah), seperti pendapat yang telah dikemukakan oleh Nurcholish 
Madjid yaitu niyat (komitmen), ihsan (untuk mendapatkan ridla Allah) dan perwujudan diri (Madjid, 1992). Atau faktor-faktor di luar masalah agama, sebagaimana pernah disinggung oleh W. F. Werthein dan dikutip oleh Taufik Abdullah, bahwa perkembangan ekonomi dapat lebih ditentukan oleh faktor birokrasi, hal ini karena peraturan dalam birokrasi sangat mempengaruhi suasana dan etika kerja (Abdullah, 1982).

Seberapapun kadar kekuatan pengaruh aspek teologi (takdir) terhadap etos kerja seseorang, sebagaimana dalam hasil penelitian di atas, jika dilakukan pembinaan dengan interpretasi yang logis dan argumentasi yang rasional, diharapkan aspek teologi ini tetap dapat menyokong peningkatan etos kerja seseorang/masyarakat. Karena dari hasil olah data yang telah dilakukan di atas, ada satu sisi menarik yang perlu diperhatikan, yaitu kenyataan bahwa etos kerja orang Sunni yang diasumsikan "sedang”, ternyata ada pada kategori "tinggi" dalam tiga variabel (motivasi kerja, pola kerja dan tekad kerja) dari lima variabel yang ada sebagai unsur etos kerja. Tidak bisa dipungkiri bahwa temuan ini memang cukup menarik.

Permasalahan etos kerja sebenarnya tidak dapat dipisahkan dari permasalahan SDM (Sumber Daya Manusia). Masalah etos kerja merupakan salah satu aspek yang tidak bisa ditinggalkan dalam persoalan SDM. Oleh karena itu, dalam rangka pembinaan dan pembentukan SDM yang berkualitas, pengembangan etos kerja manusianya pun juga harus dilakukan. Dan salah satu faktoe yang dapat mempengaruhi etos kerja seseorang adalah masalah teologi yang menjadi keyakinannya, seberapapun besar pengaruh itu. Dengan demikian, pemahaman aqidah sebagai unsur spiritualisme agama dapat menyokong peningkatan etos kerja, yang pada gilirannya akan mendasari pembentukan SDM yang berkualitas, sehingga dapat meningkatkan produktivitas masyarakat/bangsa.

Temuan yang dihasilkan dari penelitian ini diharapkan semaksimal mungkin dapat memberikan manfaat dan sekaligus menjadi kontribusi bagi pihakpihak yang terkait dengan masalah upaya peningkatan kualitas SDM, atau 
siapapun yang memiliki kepentingan dengan masalah ini dan membutuhkannya, demi peningkatan produktivitas masyarakat, terutama di era kemajuan teknologi dewasa ini.

\section{Kesimpulan}

Dari seluruh pembahasan yang telah dilakukan terhadap topik yang dikaji dapat dirumuskan beberapa kesimpulan sebagai berikut: (1) Masalah arah kecenderungan pemikiran mahasiswa terhadap aliran-aliran teologi yang ada (Jabbariyah, Qadariyah dan Sunni) mayoritas responden adalah beraliran Sunni. (2) Mengenai opini mahasiswa terhadap hal-hal yang berkaitan dengan masalah etos kerja, ternyata dari tiga kategori etos kerja (tinggi, sedang dan rendah), mayoritas etos kerja mereka adalah "tinggi". (3) Tentang ada dan tidaknya korelasi antara kecenderungan teologi dengan etos kerja, didapati bahwa korelasi yang dimaksud ternyata ada, meskipun tingkat korelasinya sangat lemah. Dikatakan demikian karena dari lima variabel etos kerja yang dikorelasikan dengan aliran-aliran dalam teologi, terdapat tiga variabel yang memiliki korelasi, dan dua variabel lainnya tidak memiliki korelasi. (4) Aliran Sunni yang diasumsikan etos kerjanya "sedang" ternyata mayoritas justru "tinggi". Ini berarti apa yang telah diasumsikan tidak sepenuhnya sesuai dengan kenyataan yang ada. Maka dapat dikatakan bahwa masalah kecenderungan teologi bukanlah satusatunya faktor yang dapat mempengaruhi etos kerja seseorang, melainkan sangat dimungkinkan adanya faktor-faktor lain di luar masalah teologi, atau bahkan di luar masalah agama. Meskipun demikian, pemahaman aqidah tetap menjadi unsur yang perlu diperhatikan sebagai salah satu faktor yang dapat mempengaruhi etos kerja seseorang.

Setelah mencermati temuan yang dihasilkan, ada beberapa hal yang perlu disampaikan sebagai saran untuk sedapat mungkin dijadikan sebagai bahan pemikiran lebih lanjut. Pengetahuan tentang aqidah Islam yang lebih mendalam perlu diberikan kepada masyarakat untuk menambah wawasan keislaman mereka, khususnya mengenai pemikiran-pemikiran dan diskusi-diskusi di antara para ulama teologi. Perlu adanya interpretasi dan pemahaman terhadap masalah takdir 
Allah secara lebih rasional, implementatif dan aplikatif, sehingga dengan

pemahaman yang tepat dapat menyokong terbentuknya etos kerja masyarakat yang lebih baik. Karena terbukanya kemungkinan-kemungkinan adanya faktor-faktor lain di luar masalah aqidah yang dapat mempengaruhi etos kerja yang tinggi, maka perlu dilakukan penelitian-penelitian labih lanjut untuk mengkaji faktor-faktor yang dimaksud. Perlu adanya tindak lanjut yang lebih riil dari penelitian ini, untuk mendukung upaya-upaya peningkatan etos kerja masyarakat dalam rangka pembinaan SDM yang berkualitas, bagi pihak-pihak yang berkompeten.

\section{Daftar Pustaka}

Abdullah, Taufik (ed.), 1982, Agama, Etos Kerja dan Perkembangan Ekonomi, LP3ES, Jakarta.

Ali, Maulana Muhammad, 1977, Islamologi, Darul Kutubil Islamiyah, Jakarta. Azwar, Saifuddin, 1999, Metode Penelitian, Pustaka Pelajar, Yogyakart.

Departemen Pendidikan Nasional 1991, Kamus Besar Bahasa Indonesia, Balai Pustaka, Jakarta.

Madjid, Nurcholish, 1992, Islam, Doktrin dan Peradaban, Penerbit Yayasan Wakaf Paramadina, Jakarta.

Muhibbin, Zainul, 2004, NU dan Masalah Produktivitas Bangsa, dalam Prosiding Seminar Nasional: Peran Serta Warga Nahdliyin dalam Pembangunan di Indonesia, Penerbit ISNU, Surabaya.

Nasution, Harun 1995, Islam Rasional, Mizan, Bandung.

Nawawi, Hadari, 2001, Manajemen Sumber Daya Manusia untuk Bisnis yang Kompetitif, Gadjah Mada University Press, Yogyakarta.

Shihab, M. Quraish, 1996, Wawasan Al-Qur'an, Mizan, Bandung.

Sugiyono, 1999, Statistika untuk Penelitian, Alfabeta, Bandung.

Syahrastani, Abu al-Fath Muhammad Abd al-Karim bin Abi Bakr Ahmad al-, t.t., Al-Milal wa al-Nihal, Dar al-Fikr, Beirut.

Weber, Max, 1982, Etika Protestan dan Semangat Kapitalisme (The Protestant Ethic and The Spirit of Capitalism), dalam Taufik Abdullah (ed.), Agama, Etos Kerja dan Perkembangan Ekonomi, LP3ES, Jakarta.

Zahrah, Muhammad Abu, 1996, Aliran Politik dan Aqidah dalam Islam, Logos Publishing House, Jakarta.

Jsh Jurnal Sosial Humaniora, Vol.1 No.2, November 2008 